\title{
Mobile Learning Application: Effect of Learning Readiness and Community Learning Toward Technology Management and Mobile Learning
}

\author{
https://doi.org/10.3991/ijoe.v17i13.26871 \\ Jamaris $\left.^{(}\right)$, Hendra Hidayat, Anggarda Paramita Muji \\ Universitas Negeri Padang, Padang, Indonesia \\ jamarisefip.unp.ac.id
}

\begin{abstract}
The use of mobile learning applications in current conditions and the challenges of learning in the digital era, has become a necessity and cannot be avoided for efficiency and effectiveness in learning anywhere and anytime. This study aims to analyze the Effect of Learning Readiness and Community Learning Toward Technology Management and Mobile Learning. Besides that, it also looks at how effective the application of mobile learning applications is in learning. This research is a quasi-experimental research. The research design used is a posttest-only design, with a sample of 150 people and selected by proportional stratified random sampling technique. Data were analyzed using Oneway Multivariate Analysis of Variance (One-way MANOVA). Analysis of the implementation of the mobile learning application using descriptive statistics. The results of this study reveal that community learning and readiness to learn together can be factors that influence student mobile learning and technology management. The application of Technology Management and Mobile Learning is very helpful in overcoming educational gaps and barriers in society and higher education, the results of the use of mobile learning applications have a very effective impact on the education process for better quality education.
\end{abstract}

Keywords - mobile learning application, learning readiness, community learning, technology management, mobile learning

\section{Introduction}

The use of information technology in learning is now widely spread. The success of today's learning cannot be separated from the use of information technology [3]. The use of mobile technology applications continues to show an increase, one of which is in the world of education known as mobile learning. Mobile learning is a unique learning approach by utilizing mobile technology, where students can access subject matter, exercises and tests that test students' abilities wherever they are [4]. Mobile learning in learning is also a very good facility in supporting learning, because learning is something that is done consciously and intentionally, therefore learning must have a better goal [1]. Learning can help students to gain various experiences. The experience can add to the personal behavior of students [2]. Mobile learning applications answer the 
constraints and weaknesses of the current learning process, such as the interaction process between teachers and students is not clear in conveying the message of learning materials, lack of information about assignments, students are afraid to ask questions in the learning process, learning is less interesting and monotonous. So, the role of the Mobile learning application which serves as a means to support and support activities in the teaching and learning process [5]. By taking advantage of the rapid development of mobile technology applications at this time and also the increasing number of mobile users, Mobile learning applications are the right answer to learning in today's digital era [6-7].

The concept of mobile learning itself, using smartphone devices [8], makes it easier for students to access subject matter without any time and place restrictions, because learning can be accessed anywhere and anytime. The choice in the use of information technology in the learning process is a basic need to be able to survive in the current learning conditions [9]. Many students rate that managing information technology is the best way to improve the quality of learning. System improvements in information technology provide great opportunities for students to increase or transform their knowledge. The application of community learning, mobile learning and technology management will not work effectively if there is no model that is suitable for students' readiness to learn [10]. Community learning is useful to assist students in the use of mobile learning [9]. With this strategy, it is hoped that the learning process will take place naturally in the form of student activities working together and collaboratively. Community learning also involves seven main components of effective learning, namely constructivism, inquiry, questioning, community learning, modeling and actual assessment. The application of community learning is in line with the readiness of students in the learning process. Readiness is the overall condition of a person who makes him ready to give a certain response and answer to a situation [11]. Readiness is a prerequisite for subsequent study. Readiness can be interpreted as a person's readiness or willingness to do something, as all the characteristics or strengths that make a person react in a certain way.

Someone who states that he is ready to learn, then that person has prepared all the needs related to learning. These needs can be in the form of physical needs or nonphysical needs. A person with good physical condition readiness such as maintaining a healthy body condition, adequate rest and others, then of course in the learning process that person will have a good level of concentration in receiving the learning material provided so that the person's participation in the learning process can occur [12]. So, the purpose of this study is to uncover and analyze the Effect of Learning Readiness and Community Learning Toward Technology Management and Mobile Learning. Besides that, it also looks at how effective the application of mobile learning applications is in learning.

The hypotheses in this study are as follows:

$\mathrm{H} 1$ : there is an effect of Community Learning and learning readiness on Technology Management and Mobile Learning. 


\section{Literature review}

\subsection{Information technology-based education quality management}

Good education is quality education and implemented through a quality process. Quality cannot be obtained just like that, it takes a breakthrough effort to achieve it. Ways to get quality education include improving strategies, approaches, objectives, methods, techniques, program improvements, supervision, system improvements, and others. Quality assurance is a system in quality management. Quality management itself is a way of managing a comprehensive and integrated organization. Quality management is directed to: a) consistently meet consumer needs, and b) achieve continuous improvement in every aspect of the organization's activities. The main objective of a quality management system is to prevent errors in the production process by ensuring that every step taken during the production process is monitored from the very beginning of the production process. If an error occurs in the production process, repairs are immediately carried out so that greater losses can be avoided. In quality management, this system has the advantage that the quality of the products produced is guaranteed, because the prevention of errors in the production process is carried out strictly. Although in the short term starting to implement a quality management system like this is relatively expensive, because various resources must be available, especially reliable human resources, in the long term this system is very profitable, because it can prevent or minimize failures in because the prevention of errors in the production process is carried out strictly.

Although in the short term starting to implement a quality management system like this is relatively expensive, because various resources must be available, especially reliable human resources, in the long term this system is very profitable, because it can prevent or minimize failures in because the prevention of errors in the production process is carried out strictly. Although in the short term starting to implement a quality management system like this is relatively expensive, because various resources must be available, especially reliable human resources, in the long term this system is very profitable, because it can prevent or minimize failures in production. process. The purpose of quality management is to improve the quality of work, increase productivity and efficiency through improving performance and improving the quality of work in order to produce products that satisfy or meet consumer needs. So, quality management is not a set of rigid rules and regulations that must be followed, but a set of procedures and processes to improve performance and improve the quality of work. The importance of paying attention to quality management is no exception in learning [13]. Management quality assurance [14], if it is built with an integrated system is the responsibility of all parties. In order to make learning management more effective and efficient, the role of information technology is needed in controlling quality management and student quality [15]. 


\subsection{Mobile learning application}

Information and communication technology is defined as a series of activities facilitated by electronic means through processing [16-17], transmission, and display of information [18-20]. Mobile learning applications act as enablers in socio-cultural transformation in various aspects of people's lives and become the main driving sector for community growth. Mobile learning applications facilitate (a) information dissemination and access to value-added information, (b) knowledge sharing processes, (c) development of skills, capacities, and competencies; and (d) development of communication networks. The important role of information technology is no exception in the form of system applications for education, which allows it to be accessed online and offline [21]. The role of this information technology system application is already important in Community Learning [22].

The implementation of Community Learning through mobile learning applications will connect students in a certain area [23]. So that learning control efforts can be carried out which lead to a quality culture. This effort must be started, because of the community's demands on the quality of education services to be able to produce quality graduates. So that it is harmonious in improving the quality of community education towards quality Community Learning [24]. because of the community's demands for the quality of education services to be able to produce quality graduates. So that it is harmonious in improving the quality of community education towards quality Community Learning [24]. because of the community's demands for the quality of education services to be able to produce quality graduates. So that it is harmonious in improving the quality of community education towards quality Community Learning [24].

\section{$3 \quad$ Research methods}

This research is a quasi-experimental research. The research design used is a posttest-only design. The experimental class is a class that uses community learning and high learning readiness. While the control class is a class that learns without using community learning and low learning readiness. The research population in this study were 500 students who took part in learning in Higher Education, a sample of 150 people, who were selected using the technique proportional stratified random sampling. The main data collection tools used in this research are Community Learning questionnaires, learning readiness, mobile learning and Technology Management. Data collection is carried out in Higher Education with the following procedure:

a) Prepare a questionnaire.

b) Provide an explanation of the instrument and how to fill it out.

c) Distribute instruments and invite students to fill in them.

d) Collecting instruments according to the plan.

Data were analyzed using One-way Multivariate Analysis of Variance (Oneway MANOVA). Multivariate test is used to test whether each factor affects the group of dependent variables. Data analysis is assisted by using the program SPSS version 22.00. 
Paper-Mobile Learning Application: Effect of Learning Readiness and Community Learning Toward...

The assessment of quantitative to qualitative data from the results of testing the mobile learning application refers to table 1:

Table 1. Converting Quantitative Data to Qualitative Data

\begin{tabular}{|l|c|}
\hline Average Score & Effectiveness of Using Mobile Learning Applications \\
\hline $80-100$ & Very Effective \\
\hline $50-79$ & Effective \\
\hline $30-49$ & Fairly Effective \\
\hline $0-29$ & Less Effective \\
\hline
\end{tabular}

\section{$4 \quad$ Results and discussion}

The results of hypothesis testing can be seen in the table 2 .

Table 2. Model Summary

\begin{tabular}{|l|c|c|}
\hline Model & F & Significant \\
\hline 1 & 5.437 & 0.024 \\
\hline 2 & 5.679 & 0.021 \\
\hline
\end{tabular}

The table 2 is a table to test the differences between the control class and the experimental class. The significant number obtained is $0.024<0.05$ then 0 rejected. That is, there are differences in mobile learning in the experimental class and the control class. While on the technology management variable, the significant number obtained is $0.021<0.05$ then 0 rejected. That is, there is a difference in Technology Management between the experimental class and the control class.

The results of the statistical analysis test show that community learning and learning readiness are effective in improving mobile learning and Technology Management learning. Readiness is the overall condition of a person who makes him ready to respond and answer in a certain way to a situation. Willingness to respond or react. Willingness arises from within a person and is also related to maturity, because maturity means readiness to carry out skills. This readiness needs to be considered in the learning process, because if students learn and there is readiness, the learning outcomes will be better. An application of mobile learning in which there is a very important analytical process that will determine the next development step [25]. Mobile learning readiness and technology management are grouped into six factors, namely (1) student readiness (2) teacher readiness (3) infrastructure (4) management support (5) school culture (6) face-to-face learning tendencies [26].

In the learning process, it is very necessary to prepare yourself to deal with it. Learning is a person's way of knowing something that cannot be done. A person can only learn about something if there is already a readiness to learn to take part in learning. There are different patterns of readiness formation within each individual. Likewise, readiness in learning is very influential on a person's personal development [10] to fi- 
nalize his willingness to learn so that a person will be easy and ready to accept something that will be learned in the learning itself [27]. The attitude, skills and behavior of a student towards taking responsibility for the learner's own learning. The result, Students who have high learning readiness will be able to follow the learning well and be able to develop their skills [11]. Based on the explanation above, it can be concluded that a healthy physical condition, good mental (emotional) condition, supportive learning needs, the learning process and learning objectives can run well where readiness affects learning outcomes, if student learning outcomes are not achieved properly, then the learning objectives cannot be achieved properly [12].

The results show that community learning and readiness to learn together contribute significantly to mobile learning and technology management. The application of community learning and learning readiness can improve mobile learning readiness and technology management [28]. The results of this study reveal that community learning and readiness to learn together can be factors that influence student mobile learning and technology management [29], [30]. Readiness is the initial condition for students who are ready to carry out a learning activity both in the sense of being physically, psychologically, and materially ready for the students themselves and being able to respond to all actions in the learning process in the classroom so that learning objectives are achieved. Students who have good learning readiness will tend to be trained to do something if they are given exercises about what they have learned [31]. If they are trained to use community learning that has been taught, it tends to affect the pattern of mobile learning and technology management [32].

The following are the benefits and application of Mobile learning Applications in learning activities:

\subsection{Online technology management}

Online-based management using an application with several required features produces careful, effective, and efficient community learning [33]. Careful means that every detail can be observed and controlled in a clear and real-time manner. Every activity in community learning can be monitored and monitored both the source and the results, especially the flow of activities can be seen clearly. As for the effectiveness, the results of each community learning management activity directly benefit both the success of community learning and the education graduates it produces. The management of community learning is clearly increasing or decreasing in quantity and/or quality. So that the benefits of each activity are felt by several components involved in the management of community learning [34]. In terms of efficiency the use of online information technology will certainly reduce the expenditure of every activity carried out, especially in terms of the use of printed paper in the form of paper. Information in and out very quickly occurs from the learning community, both from educators, students and managers. Reducing costs is a successful measure of the efficiency of online community learning management. Efficiency was also found to be related to information traffic occurring several times each day or every week. Efficiency is also obtained by students who should come to the institution to deliver test answer sheets in the conventional way. However, online, learners can use this generated application, as Figure 1. 

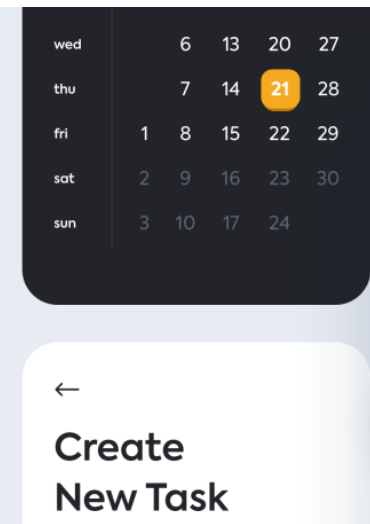

|Task Name

Friday 28, November

(ㄷ) $1: 00 \mathrm{pm}-3: 30 \mathrm{pm}$

$\theta$ Work

tor Work

Remind me

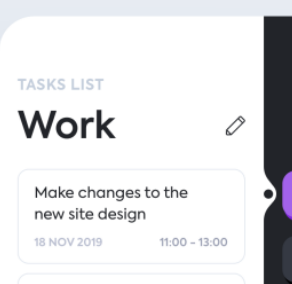

Upload Sketch to Zeplin
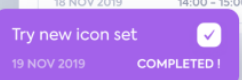

Start making user flow

for a new mobile

application

Make changes to the

old site design

21 Nov $2019 \quad$ 12:00 - 15:00

+ ADD NEW TASK
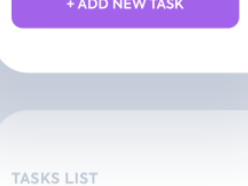

Family

CREATE TASK
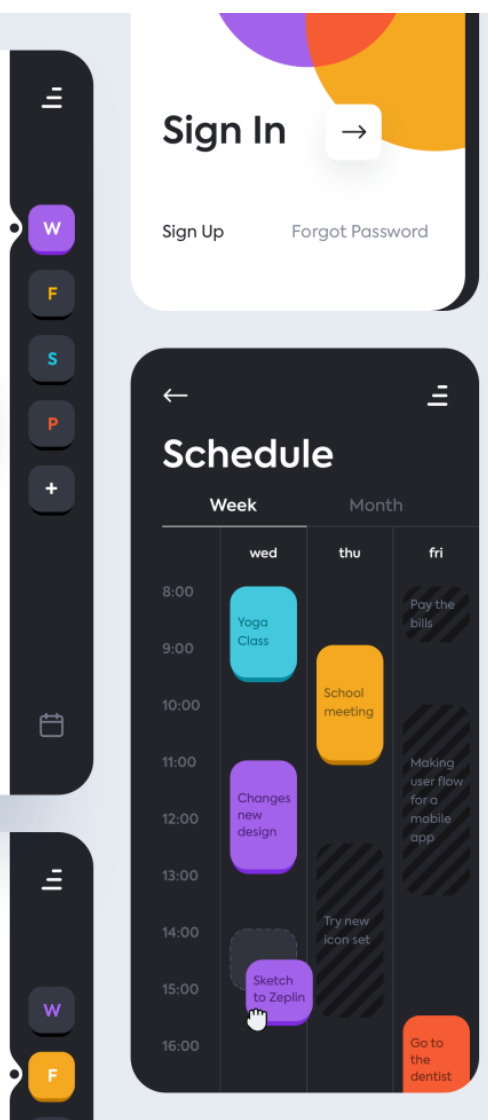

Fig. 1. Mobile Learning Application (Source: https://dribbble.comshots8585107-To-do-listMobile-applicationattachments 847752 mode $=$ media)

\subsection{Learning from various mobile learning applications on gadgets}

This application can be used to learn anywhere with any gadget using LMS facilities, Blended Learning, a combination of face-to-face and online, it does not rule out the possibility of unlimited full online learning with G-Suite from Google and Microsoft 365 for education. The use of this application has proven to be very effective in the implementation of learning by community learning. This application is very helpful in learning carried out by tutors and or educators because it is very effective in carrying out online learning.

This application can connect with several sites or websites that are already popularly used by many people. Making it possible for the development of students or students in obtaining information or other learning resources. In the implementation of learning, it is easier for educators to provide materials and tasks needed by students. Some of the effective results obtained include the search and development of materials or teaching materials that are easily obtained. 
In addition, this integrated application also has support from Google and Microsoft 365 for cloud computing. This support has many benefits, namely without fear of losing data when the computer is damaged or lost, unlimited facilities from Google and Microsoft for online storage, and its features can work together anywhere with any gadget and can monitor any activity through Google G Suite and Microsoft education. The learning community is not worried about the security of their data, because by using this application it can be stored without being seen by unauthorized parties. This application is connected to a web or site that is already widely used with unlimited capacity capabilities. So that allows the amount of data stored can be as much as possible.

\subsection{Online attendance and tutor assignment}

Learning from Various Mobile Learning Applications on Gadgets. This application provides attendance and online assignments using an android application by utilizing the Kaizala application which is integrated with Microsoft 365 and can also be used to coordinate work in the learning community itself. The features in it are integrated with Office 365, calendar, online attendance, and online tasks. The use of this application by students and tutors seems to make it easier to follow learning. Some of the benefits obtained include students being able to state their presence from home and being monitored by tutors anywhere. Feedback can also be directly done by the tutor in response to the tutor's presence online. So that some people who learn quickly know their participation in the learning process. Tutors really feel the benefits in determining the learning strategies that will be carried out at the meeting, based on the number of students present. The following can be observed applications related to online attendance and direct tutor assignments that can be given to students.

\subsection{Student, finance, and messaging apps}

The management information system uses an integrated application, consisting of student applications, finance, and notification via messages. Available features are Handling online registration, main book, cash in and out information, receipt printing, online backup system, the available graph of student numbers, and compliance.

\subsection{Work together in real-time with tutors}

This application can also work together between tutors and students, among other things when sharing a presentation with others, you will see them working with you at the same time.

Furthermore, after using various mobile learning applications that have been adapted to the needs and problems in the field, the results of testing on the effectiveness of the application of mobile learning applications at the learning activity are obtained, as follows:

This test is very necessary to see the application of mobile learning applications from several indicators and aspects that are expected to support learning. It can be seen from Figure 2 that the results obtained are quite varied and this is strongly influenced by 
various factors, especially the level of understanding in using information technology and its development. The highest results can be seen from the data results, namely the use of information technology in the form of backup storage in the cloud with a value of 96 which means it is very effective. This means that all activities and transactions are thought out and have digitally recorded documents archived virtually or in cloud storage. While the lowest scores are 2 aspects of the use of information technology, namely, the use of information technology, in partners in the form of an online financial system, and the use of information technology, in Online Attendance and Tutor Tasks, both obtained a score of 78 , with the meaning of being effective. This means that this condition is not too bad, the process of implementing and using the online information system application has been going well, but there are some conditions that have not been disciplined. These conditions and events are strongly influenced by the human and worker aspects of the agency. The role of information technology, especially in the form of online information system applications, is very helpful in the educational process [35], in education quality management [36], especially education in the community [37-40], improving the quality of education [36], education in general [41-42].

The Implementation of Mobile Learning Applications

$\rightarrow$ test I - -testII $\rightarrow$-testIII $\rightarrow$ testIV

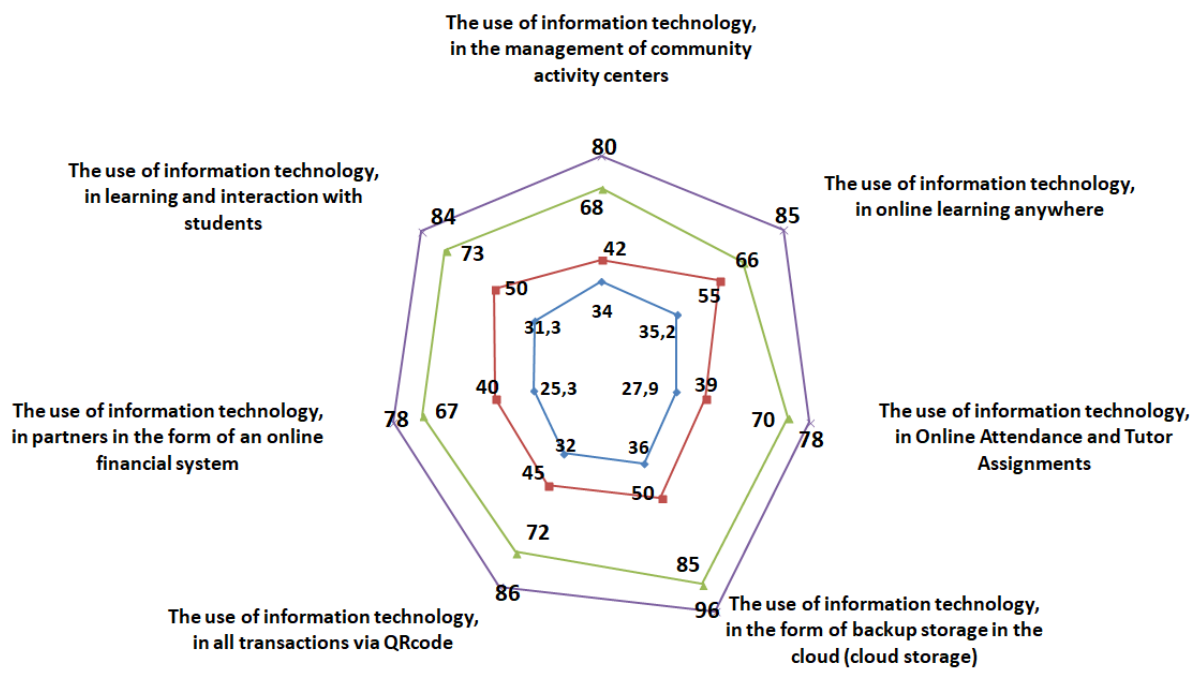

Fig. 2. The Implementation of Mobile Learning Applications

\section{Conclusion}

The development of information technology in this digital era is very influential and varied in color, especially in the field of education, not least during the COVID-19 
period. The efficiency and effectiveness of information technology is very helpful in learning, not least in Community Learning and learning readiness. Community learning and readiness to learn together can be factors that affect student mobile learning and technology management. The application of Technology Management and Mobile Learning is very helpful in overcoming educational gaps and barriers in society and higher education, the results of the use of mobile learning applications have a very effective impact on the education process for better quality education.

\section{References}

[1] Y. Baek, H. Zhang, and S. Yun, "Teachers' attitudes toward mobile learning in Korea," Turkish Online J. Educ. Technol., vol. 16, no. 1, pp. 154-163, 2017. https://scholarworks.boisestate.edu/edtech facpubs/155/

[2] S. Ortiz and M. Green, "Trends and patterns of mobile learning: A study of mobile Learning Management System access," Turkish Online J. Distance Educ., vol. 20, no. 1, pp. 161-176, 2019, https://doi.org/10.17718/tojde.522464

[3] M. UZOGLU, "Investigation Of The Studies Related To Writing Activities For Learning Purposes In Science Education Environments In Turkey i," Eur. J. Educ. Stud., vol. 5, no. 4, pp. 54-66, 2018, https://doi.org/10.5281/zenodo.1464020

[4] T. Lock, "Life Long Learning Is an Incredible Gift!.," Educ. Perspect., vol. 49, no. 1, pp. 27-28, 2017. https://eric.ed.gov/?id=EJ1170252

[5] N. Mansour, M. A. Rajab, and A. Y. . Atiquil, "Assessing Mobile Learning Readiness in Saudi Arabia Higher Education: An Empirical Study," Malaysian Online J. Educ. Technol., vol. 2, no. 2, pp. 1-14, 2007. https://files.eric.ed.gov/fulltext/EJ1086443.pdf

[6] B. Perry and M. Edwards, "Innovative Arts-Based Learning Approaches adapted for Mobile Learning," Open Prax., vol. 11, no. 3, p. 303, 2019, https://search.informit.org/doi/pdf/ $\underline{10.3316 / \text { informit.767572322361216 }}$

[7] M. Z. Asghar, E. Barberà, and I. Younas, "Mobile learning technology readiness and acceptance among pre-service teachers in Pakistan during the COVID-19 pandemic," Knowl. Manag. E-Learning, vol. 13, no. 1, pp. 83-101, 2021, https://doi.org/10.34105/j.kmel. 2021.13.005

[8] U. Yabanova and O. Demirkan, "The effects of a mobile pre-learning system with surface learning approach on academic achievement and mobile learning attitude," Educ. Process Int. J., vol. 10, no. 2, pp. 42-58, 2021, https://doi.org/10.22521/edupij.2021.102.3

[9] E. Zhu and D. M. Baylen, "From learning community to community learning: Pedagogy, technology and interactivity," EMI. Educ. Media Int., vol. 42, no. 3, pp. 251-268, 2005, https://doi.org/10.1080/09523980500161395

[10] M. Murray, "The impact of interprofessional simulation on readiness for interprofessional learning in health professions students," Teach. Learn. Nurs., vol. 16, no. 3, pp. 199-204, 2021, https://doi.org/10.1016/j.teln.2021.03.004

[11] S. Haviland, S. Robbins, V. Belur, G. Cherfrere, and D. Klieger, "Improving Workforce Readiness Skills Among Community College Adult Learners Through New Technologies:," Metrop. Univ., vol. 32, no. 1, pp. 35-53, 2021, https://doi.org/10.18060/23884

[12] G. C. Filies and J. M. Frantz, "Student readiness for interprofessional learning at a local university in South Africa," Nurse Educ. Today, vol. 104, no. June, p. 104995, 2021, https://doi.org/10.1016/j.nedt.2021.104995

[13] Lee, J. E. (2015). A Formative Intervention on Mobile Learning Community. Procedia-Social and Behavioral Sciences, 191, 68-76. https://doi.org/10.1016/j.sbspro.2015.04.655 
Paper-Mobile Learning Application: Effect of Learning Readiness and Community Learning Toward..

[14] Anastasiadou, S., \& Anastasiadis, L. (2019). Quality assurance in education in the light of the effectiveness of transformational school leadership. In Economic and Financial Challenges for Eastern Europe (pp. 323-344). Springer, Cham. https://doi.org/10.1007/978-3030-12169-3 21

[15] Ingvarson, L., \& Rowley, G. (2017). Quality assurance in teacher education and outcomes: A study of 17 countries. Educational Researcher, 46(4), 177-193. https://doi.org/10.3102/ $\underline{0013189 X 17711900}$

[16] Hariadi, B., Sunarto, M. J., \& Sudarmaningtyas, P. (2019). Hybrid learning by using brilian applications as one of the learning alternatives to improve learning outcomes in college. International Journal of Emerging Technologies in Learning, 14(10), 34-45. https://doi.org/ $\underline{10.3991 / i j e t . v 14 i 10.10150}$

[17] Ramlee, N., Rosli, M. S., \& Saleh, N. S. (2019). Mathematical HOTS Cultivation via Online Learning Environment and 5E Inquiry Model: Cognitive Impact and the Learning Activities. International Journal of Emerging Technologies in Learning, 14(24). https://doi.org/ $\underline{10.3991 / \text { ijet.v14i24.12071 }}$

[18] Muljo, H., Perbangsa, A., \& Pardamean, B. (2019). Assessment of online learning application for health education. https://www.learntechlib.org/p/217892/paper 217892.pdf

[19] Zalewski, J., \& Gonzalez, F. (2017). Evolution in the Education of Software Engineers: Online Course on Cyberphysical Systems with Remote Access to Robotic Devices. International Journal of Online Engineering, 13(8). https://doi.org/10.3991/ijoe.v13i08.7377

[20] Kurniawan, D. A., Sulistiyo, U., \& Perdana, R. (2019). E-Assessment Motivation in Physics Subjects for Senior High School. International Journal of Online \& Biomedical Engineering, 15(11). https://doi.org/10.3991/ijoe.v15i11.10843

[21] Pimmer, C., Brühlmann, F., Odetola, T. D., Oluwasola, D. O., Dipeolu, O., \& Ajuwon, A. J. (2019). Facilitating professional mobile learning communities with instant messaging. Computers \& Education, 128, 102-112. https://doi.org/10.1016/j.compedu.2018.09.005

[22] Liu, W. I., Liu, C. H., Liao, C. Y., Chao, P. R., \& Chu, K. C. (2020). Mobile community learning programme's effectiveness in case management for psychiatric nurses: A preliminary randomised controlled trial. Nurse education today, 85, 104259. https://doi.org/ 10.1016/j.nedt.2019.104259

[23] Seyfried, M., \& Pohlenz, P. (2018). Assessing quality assurance in higher education: quality managers' perceptions of effectiveness. European Journal of Higher Education, 8(3), 258271. https://doi.org/10.1080/21568235.2018.1474777

[24] Pettit, J., \& Kukulska-Hulme, A. (2011). Mobile 2.0: crossing the border into formal learning?. In Web 2.0-based E-learning: Applying Social informatics for Tertiary Teaching (pp. 192-208). IGI Global. https://doi.org/10.4018/978-1-60566-294-7.ch010

[25] J. Mahat, A. F. M. Ayub, S. Luan, and Wong, “An Assessment of Students' Mobile SelfEfficacy, Readiness and Personal Innovativeness towards Mobile Learning in Higher Education in Malaysia," Procedia - Soc. Behav. Sci., vol. 64, pp. 284-290, 2012, https://doi.org/ 10.1016/j.sbspro.2012.11.033

[26] R. C. I. Prahmana, D. Hartanto, D. A. Kusumaningtyas, R. M. Ali, and Muchlas, "Community radio-based blended learning model: A promising learning model in remote area during pandemic era," Heliyon, vol. 7, no. 7, p. e07511, 2021, https://doi.org/10.1016/j. heliyon.2021.e07511

[27] G. Hergüner, S. Buğra SON, S. Hergüner Son, and A. Dönmez, "The effect of online leearning attitudes of university Students on their Online Learning Readiness," TOJET Turkish Online J. Educ. Technol., vol. 19, no. 4, pp. 102-111, 2020. https://files.eric.ed.gov/fulltext/ EJ1272871.pdf 
Paper-Mobile Learning Application: Effect of Learning Readiness and Community Learning Toward..

[28] S. Sophonhiranrak, "Features, barriers, and influencing factors of mobile learning in higher education: A systematic review," Heliyon, vol. 7, no. 4, p. e06696, 2021, https://doi.org/ $\underline{\text { 10.1016/j.heliyon.2021.e06696 }}$

[29] C. Lwande, L. Muchemi, and R. Oboko, "Identifying learning styles and cognitive traits in a learning management system," Heliyon, vol. 7, no. 8, p. e07701, 2021, https://doi.org/ $\underline{10.1016 / j . h e l i y o n .2021 . e 07701 ~}$

[30] E. A. Pogrebinskaya, P. V. Fursova, and E. S.-M. Akhyadov, "Leadership Competency Formation in Management Students Using Mobile Learning Technologies," Propósitos y Represent., vol. 9, no. SPE3, 2021, https://doi.org/10.20511/pyr2021.v9nspe3.1269

[31] R. Christensen and G. Knezek, "Reprint of Readiness for integrating mobile learning in the classroom: Challenges, preferences and possibilities," Comput. Human Behav., vol. 78, 2018, https://doi.org/10.1016/j.chb.2017.07.046

[32] A. A. K. Miglani, "Mobile Learning: Readiness and Perceptions of Teachers of Open Universities of Commonwealth Asia.," J. Learn. Dev., vol. 4, no. 1, pp. 58-71, 2017. https://j14d.org/index.php/ej14d/article/download/163/185?inline=1

[33] Cochrane, T., \& Antonczak, L. (2013). A mobile learning community of practice: Facilitating conceptual shifts in pedagogy. In European Conference on Technology Enhanced Learning (pp. 430-435). Springer, Berlin, Heidelberg. https://doi.org/10.1007/978-3-642-40814434

[34] Seyfried, M., \& Pohlenz, P. (2018). Assessing quality assurance in higher education: quality managers' perceptions of effectiveness. European Journal of Higher Education, 8(3), 258271. https://doi.org/10.1080/21568235.2018.1474777

[35] Southard, S., \& Mooney, M. (2015). A comparative analysis of distance education quality assurance standards. Quarterly Review of Distance Education, 16(1), 55. https://www. proquest.com/openview/a37a1d56cb3fe2b4bb431c0724c32294/1?pq-origsite=gscholar $\& \mathrm{cbl}=29705$

[36] Steinhardt, I., Schneijderberg, C., Götze, N., Baumann, J., \& Krücken, G. (2017). Mapping the quality assurance of teaching and learning in higher education: the emergence of a specialty?. Higher Education, 74(2), 221-237. https://doi.org/10.1007/s10734-016-0045-5

[37] Trespalacios, J., \& Rand, J. (2015). Using asynchronous activities to promote sense of community and learning in an online course. International Journal of Online Pedagogy and Course Design (IJOPCD), 5(4), 1-13. https://doi.org/10.4018/ijopcd.2015100101

[38] Wang, L., \& Ma, Q. (2017). Community of practice: Building a mobile learning community in a higher education institution to promote effective teaching and learning. In Emerging practices in scholarship of learning and teaching in a digital era (pp. 19-38). Springer, Singapore. https://doi.org/10.1007/978-981-10-3344-5_2

[39] Traxler, J. (2010). Distance education and mobile learning: Catching up, taking stock. https://doi.org/10.1080/01587919.2010.503362

[40] Zhang, S., Liu, Q., Chen, W., Wang, Q., \& Huang, Z. (2017). Interactive networks and social knowledge construction behavioral patterns in primary school teachers' online collaborative learning activities. Computers \& Education, 104, 1-17. https://doi.org/10.1016/j.compedu. 2016.10.011

[41] Hidayat, H., Tamin, B. Y., Herawati, S., Ardi, Z., \& Muji, A. P. (2020). The Contribution of Internal Locus of Control and Self-Concept to Career Maturity in Engineering Education. Int. J. Adv. Sci. Eng. Inf. Technol, 10(6), 2282-2289. https://doi.org/10.18517/ijaseit. $\underline{10.6 .11698}$ 
Paper-Mobile Learning Application: Effect of Learning Readiness and Community Learning Toward..

[42] Tasrif, E., Saputra, H. K., Kurniadi, D., Hidayat, H., \& Mubai, A. (2021). Designing Website-Based Scholarship Management Application for Teaching of Analytical Hierarchy Process (AHP) in Decision Support Systems (DSS) Subjects. International Journal of Interactive Mobile Technologies, 16(9). https://doi.org/10.3991/ijim.v15i09.23513

\section{$7 \quad$ Authors}

Jamaris, He is a Professor in Education Science. He is a Lecturer in Department Non-formal education of Universitas Negeri Padang, Padang, Indonesia. His research areas include Non-formal education.

Hendra Hidayat, He is a Doctor in Technology and Vocational Education. He is a Lecturer in Department of Electronics Engineering Education, Engineering Faculty of Universitas Negeri Padang, Padang, Indonesia. His research areas include Technical Vocational and Education Training, and Engineering Education (e-mail: hendra.hidayat@ft.unp.ac.id).

Anggarda Paramita Muji, she is a student Doctoral in Department of Education Science, Universitas Negeri Padang, Padang, Indonesia. Her research areas include Early Childhood Education.

Article submitted 2021-08-14. Resubmitted 2021-10-02. Final acceptance 2021-10-02. Final version published as submitted by the authors. 